\title{
DINÂMICA PRODUTIVA E ORDENAMENTO TERRITORIAL DOS AGRONEGÓCIOS DO MATO GROSSO DO SUL PÓS-2003
}

Roberto César Cunha ${ }^{1}$ Fernando Rodrigo Farias ${ }^{2}$

Resumo: Os diferentes agronegócios sul-mato-grossenses constituem-se em um dos principais setores econômicos geradores de renda no estado. Entre 2008-2017, o Valor Bruto da Produção dos principais produtos do agronegócio do Mato Grosso do Sul cresceu de $R \$ 18,3$ bilhões para $R \$ 28,7$ bilhões. Nas exportações, o valor gerado em 2018, foi de US\$ 5,4 bilhões, o que representa $96,4 \%$, do valor total do estado, e 5,3\%, do valor total dos agronegócios brasileiros. Assim sendo, o objetivo geral deste texto é identificar o desempenho produtivo dos agronegócios do estado do Mato Grosso do Sul com base nos indicadores de área plantada, valor bruto da produção, produtividade e participação na pauta exportadora do estado. Para alcançar o objetivo proposto, a método de análise decorreu de a economia brasileira ter desenvolvido um ciclo dinâmico de crescimento condicionado por fatores internos e externos, entre eles: investimentos em infraestrutura, recursos naturais e consumo de massa; a liquidez financeira mundial, e a elevada demanda mundial por produtos agroalimentares e minerais.

Palavras-chave: Dinâmica produtiva. Estruturas territoriais produtivas. Diferenciação. Agronegócio. Geoecônomia.

\section{PRODUCTIVE DYNAMICS AND TERRITORIAL MANAGEMENT OF AGRIBUSINESS OF MATO GROSSO DO SUL POST-2003}

Abstract: The different agribusinesses in South-Mato Grosso are one of the main economic sectors that generate income in the state. Between 2008-2017, the Gross Value of Production of the main agribusiness products of Mato Grosso do Sul increased from $\mathrm{R} \$ 18.3$ billion to $\mathrm{R} \$ 28.7$ billion. In exports, the value generated in 2018 was US $\$ 5.4$ billion, which represents $96.4 \%$ of the total value of the state and $5.3 \%$ of the total value of Brazilian agribusiness. Therefore, the general objective of this text is to identify the productive performance of agribusinesses in the state of Mato Grosso do Sul based on the indicators of planted area, gross value of production, productivity and participation in the export tariff of the state, since this dynamism accompanied by significant changes in regional production structures. In order to reach the proposed objective, the method of analysis was derived from the Brazilian economy having developed a dynamic cycle of growth conditioned by internal and external factors, among them: investments in infrastructure, natural resources and mass consumption; the global financial liquidity, and the high world demand for agri-food and mineral products.

Keywords: Productive dynamics. Territorial productive structures. Differentiation. Agribusiness. Geoeconomics.

\footnotetext{
1 Universidade Federal de Santa Catarina, Departamento de Geociências, Florianópolis, Brasil, robertoujsma@hotmail.com, https://orcid.org/0000-0002-6190-6186.

2 Universidade Federal de Mato Grosso do Sul, Curso de Geografia, Aquidauana, Brasil fernando.rodrigo@ufms.br, https://orcid.org/0000-0001-6426-8987
} 


\section{DINÁMICA PRODUCTIVA Y ORDENAMIENTO TERRITORIAL DE LOS AGRONEGOCIOS DEL MATO GROSSO DEL SUR PÓS-2003}

Resumen: Los diferentes agronegocios sur-mato-grossenses se constituyen en uno de los principales sectores económicos generadores de renta en el estado. Entre 2008-2017, el Valor Bruto de la producción de los principales productos del agronegocio de Mato Grosso do Sul creció de $\mathrm{R} \$ 18,3$ mil millones a R \$28,7 mil millones. En las exportaciones, el valor generado en 2018, fue de US $\$ 5,4$ mil millones, lo que representa el 96,4\%, del valor total del estado, y el 5,3\%, del valor total de los agronegocios brasileños. Por lo tanto, el objetivo general de este texto es identificar el desempeño productivo de los agronegocios del estado de Mato Grosso do Sul con base en los indicadores de área plantada, valor bruto de la producción, productividad y participación en la pauta exportadora del estado. Para alcanzar el objetivo propuesto, el método de análisis se debió a que la economía brasileña desarrolló un ciclo dinámico de crecimiento condicionado por factores internos y externos, entre ellos: inversiones en infraestructura, recursos naturales y consumo de masa; la liquidez financiera mundial, y la elevada demanda mundial por productos agroalimentarios y minerales.

Palabras clave: Dinámica productiva. Estructuras territoriales productivas. Diferenciación. Agroindustria. Geoeconomía.

\section{Introdução}

O estado de Mato Grosso do Sul recebeu, em especial a partir de 2003, grande volume financeiro via Estado, o que resultou em investimentos principalmente nas áreas de infraestrutura e de complexo industrial ligado aos agronegócios, resultando em importantes alterações em sua estrutura produtiva. Essas mudanças possuem ligação direta com os investimentos em "capital ocioso" ocorridos sobretudo entre 2003 e 2014. Nesse período, ocorreram investimentos oriundos de programas, a exemplo do Programa de Aceleração do Crescimento (PAC) e do Programa de Investimento em Logística (PIL). Os efeitos de tais investimentos proporcionaram o desenvolvimento de novas estruturas institucionais e produtivas tanto nos setores da indústria e quanto nos da agricultura, acoplados ao agronegócio.

Com uma área de 357,1 mil km², o equivalente a 4,2\% do território brasileiro, e uma população de quase 2,7 milhões de habitantes (IBGE, 2019a), o estado do Mato Grosso do Sul tem nos agronegócios um dos segmentos mais importantes na 
geração de renda ${ }^{3}$. Em 2016, o Produto Interno Bruto (PIB) estadual somou 91,8 bilhões de reais, sendo $17,3 \%$ ( $R \$ 15,9$ bilhões) correspondentes à agropecuária (IBGE, 2019b). O Valor Bruto da Produção ${ }^{4}$ (VBP) das lavouras (permanentes e temporárias), em relação ao VBP do Brasil, foi de 5,1\% ( $\$$ \$ 18,8 bilhões), contra $5,6 \%$ (R $\$ 9,9$ bilhões) da pecuária (BRASIL, 2019b). Nas exportações ${ }^{5}$, dos US $\$ 5,6$ bilhões exportados pelo estado em 2018, 96,4\% (US\$ 5,4 bilhões) são produtos dos agronegócios, sendo 38,8\% (US\$2,1 bilhões) das receitas do estado obtidas com a cadeia produtiva da soja (grãos, farelo e óleo), 35,1\% (US\$1,9 bilhão), com os produtos agroflorestais, e 16,9\%, com o agronegócio de carnes (US\$ 917 milhões) (BRASIL, 2019a).

Com um total de 70,7 mil estabelecimentos rurais (IBGE, 2019d), o Mato Grosso do Sul, em 2017, foi o quinto maior produtor de grãos do país, responsável por $8 \%$ (18,7 milhões de toneladas) (CONAB, 2019) de toda a produção brasileira de grãos e o terceiro maior produtor de milho, com 10\% (9,8 milhões de toneladas) da produção do país. Além disso, o estado ocupou o segundo lugar nas produções de algodão, com 124,4 mil toneladas, e, na produção de grãos de soja, o Mato Grosso do Sul produziu, na safra de 2017, 9,1 milhões de toneladas (8\% da safra nacional), o que lhe redeu o quinto lugar no país e o terceiro lugar nacional na produção de celulose, com 14,6\% (12,8 milhões de metros cúbicos) (IBGE, 2019e).

Nos agronegócios de carnes, o rebanho bovino atingiu, em 2017, 21,4 milhões de cabeças (quarto maior rebanho do Brasil); o suíno, 1,4 milhão de cabeças; e a produção de cabeças de frangos foi de mais de 25,7 milhões (IBGE, 2019a). Além disso, a produção de cana-de-açúcar, no estado pantaneiro, ficando

\footnotetext{
${ }^{3}$ Diferentemente de uma vasta bibliografia que associa agronegócio à produção de commodities e ao tamanho da área, definem-se, aqui, os agronegócios como uma cadeia produtiva "que envolve desde a fabricação de insumos, passando pela produção nos estabelecimentos agropecuários, pela transformação e o seu consumo final" (CONTINI et al., 2006, p. 6).

4 É a expressão monetária da soma de todos os bens e serviços produzidos em determinado território econômico, num dado período de tempo. O Valor Bruto da Produção Agropecuária representa uma estimativa da geração de renda do meio rural, revertendo em uma variável relevante para acompanhamento do desempenho do setor na sua íntegra. O Valor Bruto da Produção Agropecuária mostra a evolução do desempenho das lavouras e da pecuária ao longo do ano e corresponde ao faturamento bruto dentro do estabelecimento; é calculado com base na produção da safra agrícola e da pecuária, e nos preços recebidos pelos produtores nas principais praças do país, dos 26 maiores produtos agropecuários do Brasil. O valor real da produção, descontada a inflação, é obtido pelo índice Geral de Preços - Disponibilidade Interna (IGP-DI), da Fundação Getúlio Vargas (FGV). Sua periodicidade é mensal com atualização e divulgação até o dia 15 de cada mês. A estimativa do VBP é elaborada pela Coordenação-Geral de Estudos e Análises (CGEA) do Departamento de Crédito e Estudos Económicos (DCEE), da Secretaria de Política Agrícola (SPA) (BRASIL, 2018b).

5 Os outros produtos das exportações do estado são: $9,7 \%$ referente à carne bovina, $4,8 \%$ carne de frango, 2,5\% minério de ferro, 1,6 manganês, 1,5\% milho em grão, 0,69\% algodão, 3,1\% açúcar de cana, $1,5 \%$ couros, $1,32 \%$ miudezas animais (BRASIL, 2019a).
} 
em quarto lugar nacional, alcançou 46,9 milhões de toneladas, auferindo um VBP de $\mathrm{R} \$ 5,04$ bilhões.

Diante do dinamismo e da representatividade dos agronegócios sul-matogrossenses, este texto tem como objetivo desvendar o desempenho geoeconômico dos agronegócios do Mato Grosso do Sul e as alterações ocorridas nas estruturas regionais de produção pós-2003. Justificam-se os anos pós-2003 em razão de a economia brasileira ter desenvolvido um ciclo de crescimento condicionado por fatores internos e externos. Internamente, os investimentos foram assentados em três frentes - infraestrutura, recursos naturais e consumo de massa. Externamente, contribuíram a liquidez financeira mundial, a taxa de juros baixa no mundo, os investimentos externos diretos e a elevada demanda mundial por produtos agroalimentares e minerais (BIELSCHOWSKY, 2013; BARBOSA, 2013; ESPÍNDOLA, 2016). Esse ciclo, por sua vez, induziu os agronegócios do Mato Grosso do Sul a uma nova dinâmica na divisão nacional e internacional do trabalho6.

Tendo em vista a grande diversidade dos segmentos no interior dos agronegócios, procurou-se destacar o desempenho das atividades dentro da porteira, com ênfase para as lavouras (temporárias e permanentes) e a pecuária?. Para tanto, foram selecionados os principais produtos com representatividade na produção, área plantada, Valor Bruto da Produção, rentabilidade e participação na pauta exportadora sul-mato-grossense. Ainda do ponto de vista metodológico, utilizou-se a divisão mesorregional do estado do Mato Grosso do Sul definida pelo Instituto Brasileiro de Geografia e Estatística (IBGE, 2012).

Na elaboração deste artigo, optou-se pela abordagem exploratória, que adota a busca de informações a respeito de certo assunto e envolve o levantamento bibliográfico e documental. Foram feitas análises de diferentes artigos, livros e teses,

\footnotetext{
${ }^{6}$ O histórico da ocupação territorial e de suas estruturas produtivas do estado de Mato Grosso do Sul é objeto de estudos envolvendo diversos pesquisadores da área geoeconômica. Dentre eles, destacam-se Mamigoniam (1986), sobre a ocupação e as origens dos frigoríficos na região de Corumbá; Oliveira (2000a; 2000b; 2000c; 1998), sobre cadeias produtivas, sobretudo, soja e carne, também pesquisas relacionadas a fatores históricos de desenvolvimento territorial do estado e a articulação econômica e social entre os municípios do Mato Grosso do Sul. Lamoso (2016) articula a economia do estado com o Centro Dinâmico do Brasil, bem como com as relações internacionais de Mato Grosso do Sul, envolvendo as principais cadeias produtivas no que tange ao agronegócio, comércio, investimentos e fronteira. $\mathrm{E}$ Bertholi (2012; 2006), sobre o processo de ocupação territorial e o desenvolvimento do dinamismo capitalista de Mato Grosso do Sul, com base na pecuária, vinculada ao desenvolvimento dos ciclos econômicos.

7 Esses segmentos dividem-se em: (1) pré-porteira - indústrias de bens de capital e indústrias químicas e de embalagens; (2) dentro da porteira - agropecuária, que corresponde às lavouras permanentes, lavouras temporárias, extrativismo vegetal e produção pecuária; e (3) pós-porteira agrosserviços. Para uma tipologia da diversidade dos segmentos dos agronegócios, ver Gonçalves (2005).
} 
visando avaliar e situar a bibliografia relativa à temática exposta. Operacionalmente, o artigo foi desenvolvido com base em parâmetros bibliográficos e documentais, fundamentando-se em fontes primárias e secundárias.

O levantamento de dados estatísticos foi realizado nos relatórios da Produção Agrícola Municipal (PAM) e no Levantamento Sistemático da Produção Agrícola (LSPA), ofertados pelo Instituto Brasileiro de Geografia e Estatística (IBGE). Buscaram-se, ainda, informações publicadas pela Secretaria do Estado de Meio Ambiente, Desenvolvimento Econômico, Produção e Agricultura Familiar (SEMAGRO), nos relatórios do Ministério da Agricultura, Pecuária e Abastecimento (MAPA), e nos da Companhia Nacional de Abastecimento (CONAB); nos relatórios técnicos do Ministério do Desenvolvimento da Indústria e do Comércio Exterior (MDIC), do Banco Nacional de Desenvolvimento Econômico e Social (BNDES) e da Secretaria Estadual de Planejamento e Coordenação Geral, Desenvolvimento Econômico do Mato Grosso do Sul (SEMADE). Dentre as fontes secundárias, destacam-se artigos em periódicos indexados, teses, dissertações, livros e sítios de entidades empresariais e governamentais, na internet.

Estruturalmente, o texto está dividido, além da introdução e conclusão, em mais três partes, abordando: (i) da ocupação territorial às transformações nas estruturas agropecuárias do estado; (ii) o desempenho da produção e da exportação dos principais produtos dos agronegócios do Mato Grosso do Sul; (iii) e as distribuições territoriais dos agronegócios.

\section{Da ocupação territorial às transformações nas estruturas agropecuárias do Mato Grosso do Sul: uma síntese ${ }^{8}$}

O Estado de Mato Grosso do Sul apresenta algumas particularidades importantes que precisam ser destacadas. Dentre elas, podemos mencionar o fato de estar localizado em áreas de fronteiras internacionais com as Repúblicas do Paraguai e da Bolívia na sua parte sul e sudoeste do estado. Faz divisa com cinco estados brasileiros: Paraná, São Paulo, Minas Gerais, Goiás e Mato Grosso.

O fator localização geográfica é considerado pelos principais pesquisadores do estado como um aspecto positivo e de potencial geoeconômico em virtude de sua

\footnotetext{
${ }^{8}$ Não será possível aprofundamento do processo histórico no que tange à formação socioespacial de Mato Grosso do Sul. Sendo assim, a leitura dos respectivos autores citados na nota 4 será útil para uma compreensão mais aprofundada. Além disso, o histórico da ocupação territorial e suas transformações estão pautados em documentos históricos oficiais desenvolvidos pelos órgãos científicos responsáveis pelo desenvolvimento de pesquisas econômicas, a exemplo do SEMADE-MS.
} 
centralização diante de importantes centros consumidores para o agronegócio. O estado possui uma área alagadiça do Pantanal, o equivalente a 89 mil km²; até 1977, Mato Grosso do Sul pertencia ao atual território do Mato Grosso.

Essas particularidades fazem com que a referida unidade federativa apresente diferentes estruturas produtivas na formação de sua economia, com regiões com distintas especialidades, levando em conta as limitações e potencialidades, sejam elas de ordem natural, econômica e/ou socioespacial. Possui áreas de influência socioeconômica entre as regiões Sul, Sudeste e Centro Oeste, fazendo com que as mesorregiões do Estado apresentem diferentes composição em sua base econômica.

Apesar de o Estado de Mato Grosso do Sul existir oficialmente a partir de $1977^{9}$, o processo de ocupação territorial iniciou-se ainda no século XVII. De acordo com a SEPLAN (1990, p. 34), foi por meio do movimento de extração do ouro (século XVII), principalmente na região de Cuiabá, atual Estado do Mato Grosso, que se deu o início de seu processo de ocupação territorial.

Bertholi (2006, p. 29-30) esclarece que o desenvolvimento territorial inicial que originou o atual Mato Grosso do Sul aconteceu por meio de "três portas de entrada ao espaço" - Pantanal, Planalto e Sul do Brasil (Figura 1). O primeiro refere-se à região pantaneira, via rio Paraguai, de maneira especial a região de Corumbá. O segundo diz respeito ao movimento de ocupação em direção ao Oeste devido ao movimento aurífero, oriundo de Minas Gerais e região de Cuiabá. O terceiro relaciona-se ao movimento de ocupação via Sul do Estado, pela região de Dourados, com desenvolvimento de importante região do agronegócio.

${ }^{9}$ Criado por intermédio da Lei Complementar $n^{\circ} 31$, de 11 de outubro de 1977, aprovada pelo congresso nacional durante o governo Geisel. 
Figura 1 - Entradas de ocupação do Mato Grosso do Sul entre o séc. XVIII e XX

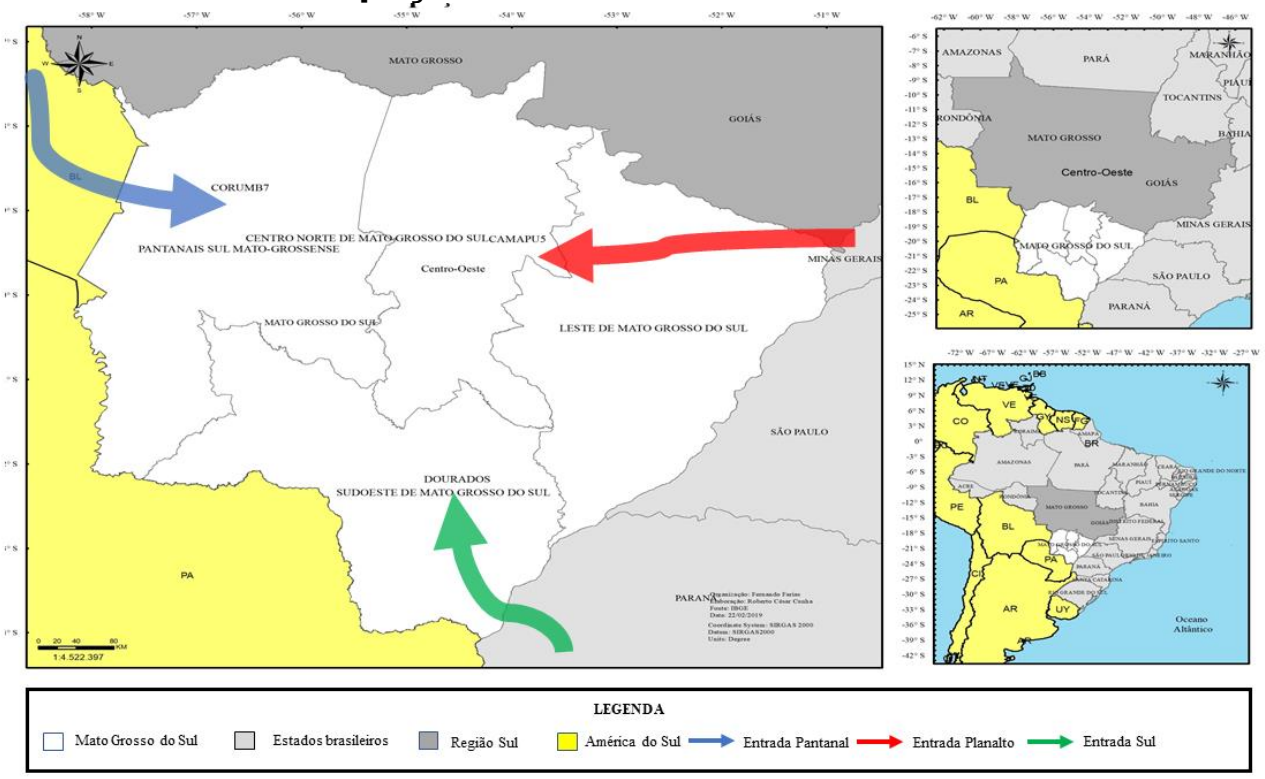

Fonte: Adaptado de Bertholi (2006). Elaboração: autores

No Quadro 1, com base em Bertholi (2006, p. 20), observa-se o processo resumido de "arrumação e organização espacial da produção pecuária e da instituição da identidade Sul-mato-grossense pode ser entendido a partir de oito intensos momentos".

\section{Quadro 1 - Movimentos para formação do Mato Grosso do Sul}

$1^{\circ}-$ Mineração no século XVIII.

$2^{\circ}$ - Organização fundiária após a Guerra do Paraguai, no século XIX.

$3^{\circ}$ - Atuação monopolista da Cia. Matte Laranjeira, entre o fim do século XIX e início do XX.

$4^{\circ}$ - Expansão dos capitais estrangeiros (charqueadas) e do mercado internacional, antes e após a Primeira Grande Guerra.

$5^{\circ}$ - Expansão do mercado de carne, vinculado à implantação dos frigoríficos no estado de São

Paulo. Intensificação da rede de transporte ferroviário pela Noroeste do Brasil, entre a primeira e a segunda metade do século XX.

$6^{\circ}$ - Atuação de políticas de Estado, mais precisamente a "marcha para o Oeste" e a expansão das "fronteiras agrícolas", marcando a fase de expansão de novas culturas pelo cerrado.

$7^{\circ}$ - Efeitos da crise da década de 1980, ocorrendo uma reorganização interna da produção.

$8^{\circ}$ - Desenvolvimento do processo de abertura e consolidação dos mercados interno e externo.

Fonte: Adaptado de Bertholi (2006). Elaboração: autores

Além do mais, alguns ciclos econômicos, que fizeram parte de seu histórico de desenvolvimento, permaneceram, ainda na atualidade, como importantes setores. Citase o caso da mineração, iniciado a partir do século XIX e que ainda está presente no atual desenvolvimento econômico do estado, em especial nos municípios de Corumbá, Campo Grande e Bodoquena.

O processo de povoamento que acelerou a dinâmica de desenvolvimento do setor agropecuário ocorreu principalmente na primeira metade do século XX decorrente dos movimentos das migrações internas. Com isso, foi criada, durante o governo de 
Getúlio Vargas, na década de 1940, a colônia agrícola de Dourados, uma importante região produtiva do agronegócio do Estado.

Apesar de o desenvolvimento do sistema agropecuário, que representa o atual dinamismo dos agronegócios do estado, ter iniciado, segundo a Bertholi (2006), em fins do século XVII e início do XVIII, o desenvolvimento mais intenso desse setor ocorreu a partir do século $X X\left(5^{\circ}\right.$ movimento), sobretudo, em decorrência da construção da ferrovia Corumbá-MS a Bauru-SP. Esse fator histórico de desenvolvimento infraestrutural acabou ajudando na dinamização do processo de escoamento da produção agrícola do Mato Grosso do Sul ao centro dinâmico do país (Região Sudeste).

Ademais, não é desnecessário destacar os fatores recentes do desenvolvimento de suas estruturas produtivas com participação significativa do setor do agronegócio de Mato Grosso do Sul. Conforme Oliveira (1996), a dinâmica dos grandes investimentos no Mato Grosso do Sul provocou as alterações atuais da base produtiva do estado, especialmente em virtude do grande volume de investimentos recebidos a partir de 2000 via BNDES. Ainda em Oliveira (1996), é salientado que essas inversões possuem ligação com o processo embrionário de investimentos ocorrido a partir da década de 1990, uma vez que elementos da nova fronteira agrícola e produtiva começaram a se intensificar. Os setores que receberam tais investimentos foram os de papel e celulose, sucroalcooleiras, abatedouros de aves; setor de bebidas; mineração; frigoríficos; laticínios; curtumes; entre outros. O resultado disso tudo foi o aumento significativo no VBP, na quantidade produzida, no avanço da área plantada e nas exportações.

\section{Desempenho da produção e da exportação dos principais produtos dos agronegócios sul-mato-grossense}

O PIB do estado do Mato Grosso do Sul atingiu, em 2016, 91,8 bilhões de reais a preços correntes. Entre 2003 e 2016, o crescimento acumulado foi de 70 bilhões de reais (IBGE, 2019f). Na agropecuária, constata-se importância significativa na geração de renda na economia do estado. Nos últimos dez anos, o VBP na agropecuária passou de $R \$ 18,3$ bilhões em 2008 , para $R \$ 28,7$ bilhões em 2017, o que representa um crescimento da ordem de 56,8\% (BRASIL, 2018b).

Em 2017, o valor gerado de $\mathrm{R} \$ 28,7$ bilhões representou 5,3\% de todo o VBP gerado pelo agronegócio brasileiro. No mesmo ano, o VBP das lavouras sul-matogrossenses ( $\mathrm{R} \$ 18,8$ bilhões) participava com 5,1\% do total gerado nas lavouras brasileiras ( $\mathrm{R} \$ 364,5$ bilhões). Na pecuária, o VBP, entre 2008 e 2017, aumentou de $R \$ 8,4$ bilhões para $R \$ 10$ bilhões, o que correspondeu a $5,6 \%$ do total de valor da 
pecuária brasileira (175,6 bilhões). Somente o VBP da cana-de-açúcar cresceu, no mesmo período, de 1,1 bilhão para 5,04 bilhões, representando $26,8 \%$ do total gerado na produção do estado em 2017 (BRASIL, 2018b).

Desagregando-se o VBP, verifica-se que quase $100 \%$ do total do valor gerado pelos agronegócios na agricultura do Mato Grosso do Sul está nas lavouras temporárias ${ }^{10}$. Esse cresceu de $\mathrm{R} \$ 3,8$ bilhões para $\mathrm{R} \$ 18,7$ bilhões (aumento real de 4,9 vezes), cresceu no acumulado próximo de $R \$ 15$ bilhões, com taxa de desenvolvimento anual de 13,4\% (Gráfico 1).

\section{Gráfico 1 - Valor Bruto da Produção das lavouras temporárias do Mato Grosso do Sul}

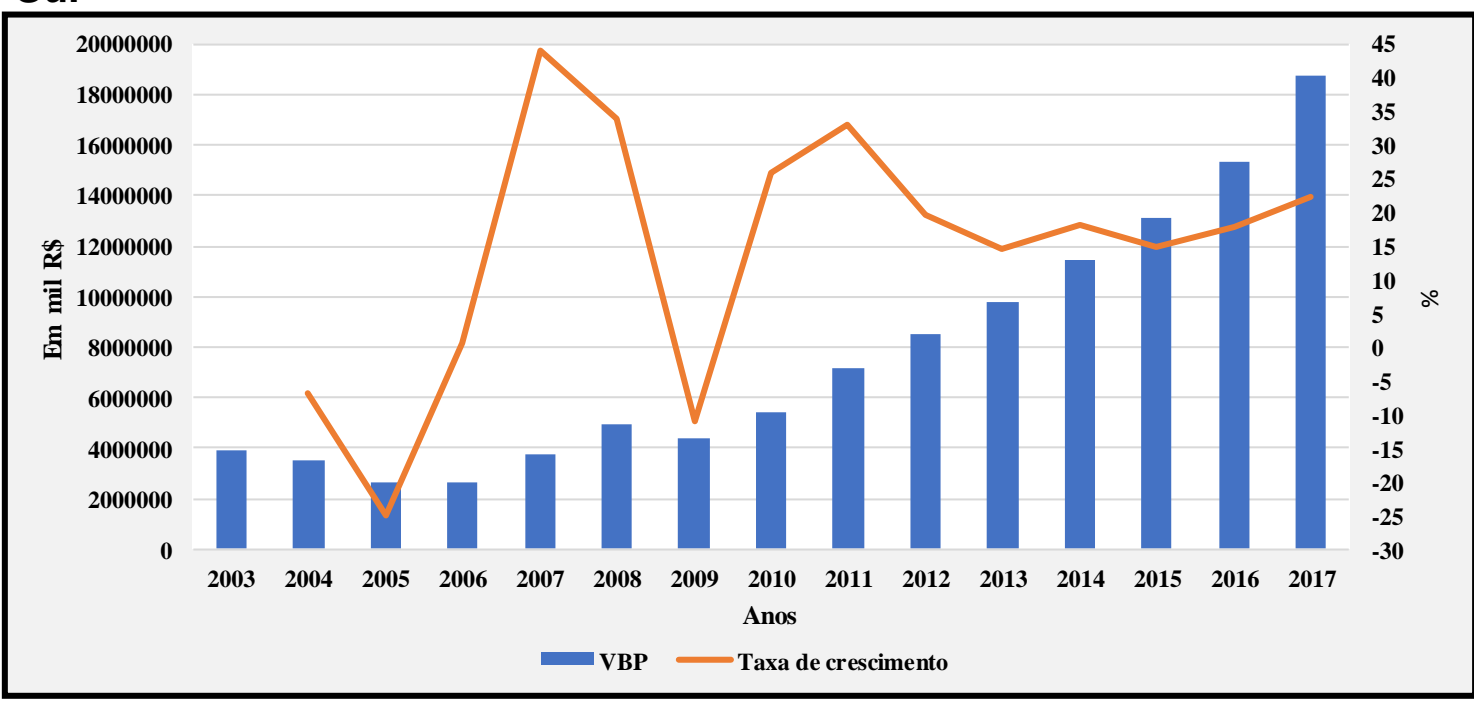

Fonte: IBGE (2019a). Elaboração: autores

Em termos de produto das lavouras temporárias, conforme o Gráfico 2, o VBP da cultura de soja no Mato Grosso do Sul passou de $\mathrm{R} \$ 2,3$ bilhões, em 2003, para 8,9 bilhões, em 2017, representando 7,5\% do VBP do total dessa cultura no Brasil (R\$ 118,5 bilhões), consolidando o estado como quinto gerador de renda de soja no país. Destaca-se, além disso, o crescimento do valor verificado na produção de milho, que passou de $\mathrm{R} \$ 755$ milhões para $\mathrm{R} \$ 3,4$ bilhões no período exposto, tornando o Mato Grosso do Sul o quarto maior estado brasileiro de VBP de milho, com 7,1\% do VBP nacional da cultura. Na cultura da cana-de-açúcar, o VBP aumentou de $\mathrm{R} \$ 254$ milhões para $R \$ 5,04$ bilhões, totalizando $7,3 \%$ de todo o VBP do Brasil ( $R \$ 68,3$ bilhões), posicionando o estado em quarto lugar nacional. Entre 2003 e 2017, no

\footnotetext{
10 O VBP das lavoras permanentes do Mato Grosso do Sul, em 2017, ficou aproximadamente em R\$ 100 milhões. Três produtos destacam-se: borracha, com $\mathrm{R} \$ 44,2$ milhões (quarto maior do Brasil); banana, com $\mathrm{R} \$ 19,7$ milhões; e laranja, com $\mathrm{R} \$ 14,2$ milhões. Esses produtos representam 78,3\% de todo VBP das lavouras permanentes no estado.
} 
estado, o crescimento da renda da cana-de-açúcar alcançou cerca de $\mathrm{R} \$ 4,7$ bilhões, o que representa quase vinte vezes mais.

Esses três produtos são responsáveis por $92,2 \%$ de todo o VBP da agricultura do território sul-mato-grossense. Ademais, destaca-se o volume do VBP da mandioca que, em 2003, registrou $R \$ 93,4$ milhões e, em 2017 , alcançou a cifra de $R \$ 346,9$ milhões, tornando-se o maior gerador de VBP da região Centro-Oeste desse produto. E, ainda na análise do Gráfico 2, outra cultura, o algodão herbáceo, também apresentou aumento nos valores auferidos no período de 2003-2017, mesmo se comportando de maneira mais instável. No início da série, o faturamento dentro dos estabelecimentos rurais desse produto foi de $\mathrm{R} \$ 199,5$ milhões; no último ano, a cifra de $R$ \$222,3 milhões, sendo o maior valor alcançado de $R$ \$ 340,7 milhões em 2011.

\section{Gráfico 2 - Valor Bruto da Produção dos produtos das lavouras temporárias do Mato Grosso do Sul}

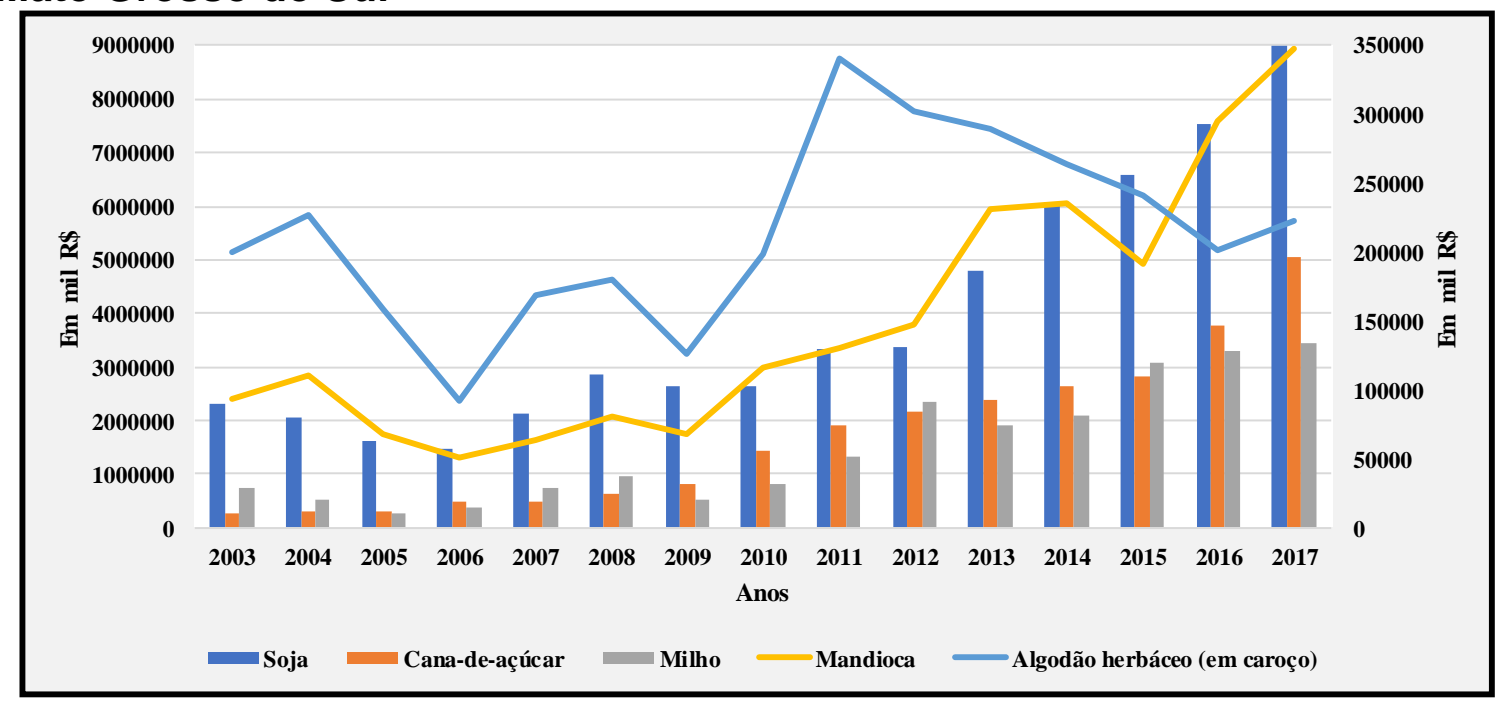

Fonte: IBGE (2019a). Elaboração: autores

A dinâmica favorável do VBP nas lavouras sul-mato-grossenses obteve desempenho harmônico com o aumento da área plantada das culturas temporárias, como demonstra a Tabela 1. Entre 2003 e 2017, a expansão da área cultivada ficou na casa de 2,7 milhões de hectares (105\%), passando de 2,57 milhões de hectares para 5,27 milhões de hectares. Essa ampliação significativa adveio, principalmente, na área plantada da soja, saindo, do início do período em tela, de 1,41 milhão de hectares para 2,62 milhões no final (aumento acumulado de 85,8\%), um incremento de terras plantadas de 1,21 milhão de hectares. Toda área de soja equivale, praticamente, a $50 \%$ do total das lavouras temporárias. 


\begin{tabular}{|c|c|c|c|c|c|c|c|}
\hline & 2003 & 2005 & 2008 & 2010 & 2012 & 2015 & 2017 \\
\hline \multicolumn{8}{|c|}{ Área plantada (em hectares) } \\
\hline L. & 2570366 & 311519 & 3237782 & 3245163 & 3813582 & 4744300 & 5273371 \\
\hline Soja & 1412307 & 203817 & 1732031 & 1732492 & 1814136 & 2350927 & 2620857 \\
\hline Cana-de- & 120534 & 136803 & 252544 & 399408 & 558664 & 546099 & 661906 \\
\hline Milho & 709198 & 565997 & 987680 & 873861 & 1244808 & 1681672 & 1832510 \\
\hline Mandioca & 22953 & 33012 & 29056 & 26690 & 30902 & 48025 & 31805 \\
\hline Algodão & 43725 & 63882 & 44224 & 38740 & 61919 & 30724 & 28841 \\
\hline \multicolumn{8}{|c|}{ Quantidade produzida (em toneladas) } \\
\hline Soja & 4090892 & 371851 & 4570771 & 5340462 & 4594359 & 7305608 & 9101890 \\
\hline Cana-de- & 9030833 & 951381 & 2136203 & 3479566 & 3776146 & 4392400 & 4693019 \\
\hline Milho & 3071632 & 129190 & 3675526 & 3782946 & 6477070 & 9727809 & 9821727 \\
\hline Mandioca & 485289 & 538754 & 572975 & 543303 & 634529 & 1004216 & 690752 \\
\hline Algodão & 159060 & 176131 & 179155 & 149369 & 221224 & 137724 & 131210 \\
\hline \multicolumn{8}{|c|}{ Rendimento médio (em quilogramas por hectare) } \\
\hline Soja & 2898 & 1836 & 2639 & 3082 & 2534 & 3108 & 3473 \\
\hline Cana-de- & 74923 & 69543 & 84587 & 87118 & 67592 & 80498 & 70902 \\
\hline Milho & 4333 & 2711 & 3798 & 4329 & 5204 & 5785 & 5361 \\
\hline Mandioca & 21175 & 16581 & 19729 & 20356 & 20534 & 22699 & 21718 \\
\hline Algodão & 3645 & 2764 & 4051 & 3855 & 3573 & 4483 & 4549 \\
\hline
\end{tabular}

Fonte: IBGE (2019a). Elaboração: autores

Em segundo lugar, o milho representa cerca de 34,7\% das terras ocupadas com lavouras temporárias no Mato Grosso do Sul. O crescimento entre os anos da série ficou em 1,12 milhão de hectares, que estampa uma taxa de elevação de 158,3\% - saiu de 709 mil hectares para 1,83 milhão. A cana-de-açúcar, que ocupa a terceira colocação, sai de 120,5 mil hectares para 661,9 mil (no acumulado, cresceu 5,5 vezes) e representa $12,5 \%$ do território das lavouras temporárias do estado. Para mais, a cultura da mandioca e a do algodão configuram $2,8 \%$ das lavouras, tendo a primeira se expandido territorialmente, atingindo, em 2017, 31,8 mil hectares, e a segunda apresentando retração em $34 \%$ no referido intervalo de tempo, ficando com 28,8 mil hectares no derradeiro ano.

Ainda na Tabela 1, observa-se que a maioria dos produtos das culturas temporárias obtiveram resultados positivos na expansão da quantidade produzida. As lavouras de soja, em 2003, produziram 4,09 milhões de toneladas de grãos e, em 2017, avançaram para 9,1 milhões, um aumento percentual de 122,4 (5,01 milhões de toneladas). Com isso, o estado sublinhou-se em quinto lugar com $8 \%$ da produção nacional. No mesmo intervalo, a cana-de-açúcar majorou 37,8 milhões de toneladas, saiu de 9,03 milhões para 46,9 milhões de toneladas (crescimento de 419,3\%), tornouse o quarto produtor do país. Semelhante a isso, o milho dilatou sua produção de 3,07 milhões para 9,8 milhões de toneladas (aumento de 3,2 vezes, 10\% da quantidade produzida na federação), evoluindo para a terceira posição do Brasil. Com menos impulso dinâmico, a produção de mandioca avançou cerca de $42 \%$, saindo de 485 mil 
para 690 mil toneladas. Destoando dos demais bens agrícolas, o algodão herbáceo em caroço obteve decréscimo na produção equivalente a $17,3 \%$ no período, passando de 159 mil para 131 mil toneladas.

Do mesmo modo, verifica-se o aumento da produtividade média em três dos produtos em análise (Tabela 1). O maior índice ficou com o algodão, com 24,8\%, seguido do milho, com 23,7\%, depois pela soja, com 19,8\%. O rendimento médio da mandioca estabilizou-se no período, enquanto a cana-de-açúcar obteve, ao longo do tempo, instabilidade, terminando com taxa negativa de 5,3\%.

Quando se faz a relação entre essas quatro variáveis das lavouras temporárias ${ }^{11}$ no Mato Grosso do Sul, nota-se que: (i) a produção global de grãos $(165,2 \%)$ cresceu mais que a área plantada $(83,3 \%$ ) e a produtividade média (75\%), porém menos que o VBP das lavouras temporárias (392\%); (ii) todos os produtos das lavouras temporárias expandiram a área plantada com exceção do algodão (perda de área para lavouras mais rentáveis como soja e milho), que, por sua vez, também, diminuiu a quantidade produzida; foi atenuada, contudo, pelo dinamismo da produtividade média, a qual, no período, avançou 904 quilogramas por hectares; (iii) a instabilidade na produtividade da cana-de-açúcar decorre de problemas climáticos sazonais desencadeados pelo fenômeno El Niño; (iv) o crescimento da produção de soja sul-mato-grossense poderia estar diretamente associado à expansão da área plantada $^{12}$. Entretanto, segundo Espíndola e Cunha (2015), além das boas condições edafoclimáticas, os preços favoráveis e as medidas político- institucionais ${ }^{13}$ explicam-se

\footnotetext{
11 Segundo dados do IBGE (2019a), as lavouras permanentes no estado do Mato Grosso do Sul tiveram crescimento positivo em área cultivada de $34,7 \%$, de 2003 a 2017. A cultura da banana sofreu redução, nesse período, de $40,3 \%$ da área plantada e 36,4\% em quantidade produzida, e 6,2\% de aumento na produtividade média. Na produção da borracha, no mesmo espaço de tempo, houve avanço de mais de dez vezes na área plantada, impulso dinâmico de quatorze vezes na produção e $28,3 \%$ de elevação no rendimento médio de quilograma por hectare. A lavoura de laranja apresentou crescimento de $123,7 \%$ na área de cultivada, aumento de $431,9 \%$ na produção e $98,7 \%$ na produtividade média no período em tela.

12 Cabe lembrar, conforme Embrapa (2019, p. 1), que "esse crescimento tem uma peculiaridade que deve ser considerada. A maior expansão da cultura, especialmente na última década, se deu em áreas já antropizadas, antes ocupadas com pastagem, na sua maioria, com algum grau de degradação. A expansão da área cultivada com cana-de-açúcar também está se dando em áreas de pastagens degradadas".

13 Dentre as políticas públicas do Governo Federal, destacam-se: (a) Política Nacional de Segurança Alimentar e Nutricional (PNSAN); (b) Programa Nacional de Alimentação Escolar (PNAE); (c) Programa de Aquisição de Alimentos (PAA); (d) Programa de Garantia de Preços para a Agricultura Familiar (PGPAF). Para o conjunto do agronegócio, o governo brasileiro direcionou o BNDES e o Banco do Brasil como principais agentes do financiamento agropecuário (PADILHA; ESPÍNDOLA, 2015); além do progressivo sistema de inovações tecnológicas, tanto de empresas privadas e públicas, sobretudo, da Embrapa Soja. Ver detalhes em Espíndola e Cunha (2015), e em Cunha e Espíndola (2016).
} 
igualmente pelo aumento da produtividade e pela crescente inserção no mercado internacional, ou seja, são fruto das combinações geográficas ${ }^{14}$.

Na pecuária, enquanto o VBP, entre 2008-2017, da produção de bovinos cresceu $15,6 \%$, passando de $R \$ 6,4$ bilhões para $R \$ 7,4$ bilhões (por pico de $R \$ 9,1$ bilhões em 2014), o valor da produção de suínos foi expandido em $87,5 \%$, saindo de $R \$ 320$ milhões para $R \$ 600$ milhões, e o do frango cresceu $23 \%$, passando de $R \$ 1,3$ bilhão para $R \$ 1,6$ bilhão - em 2016 atingiu $R \$ 1,79$ bilhão (Gráfico 3). Em contrapartida, a renda auferida do leite teve atividade negativa de 46\%, passando de $R \$ 230$ milhões para $R \$ 124$ milhões.

\section{Gráfico 3 - Valor Bruto da Produção dos produtos da pecuária no Mato Grosso do Sul}

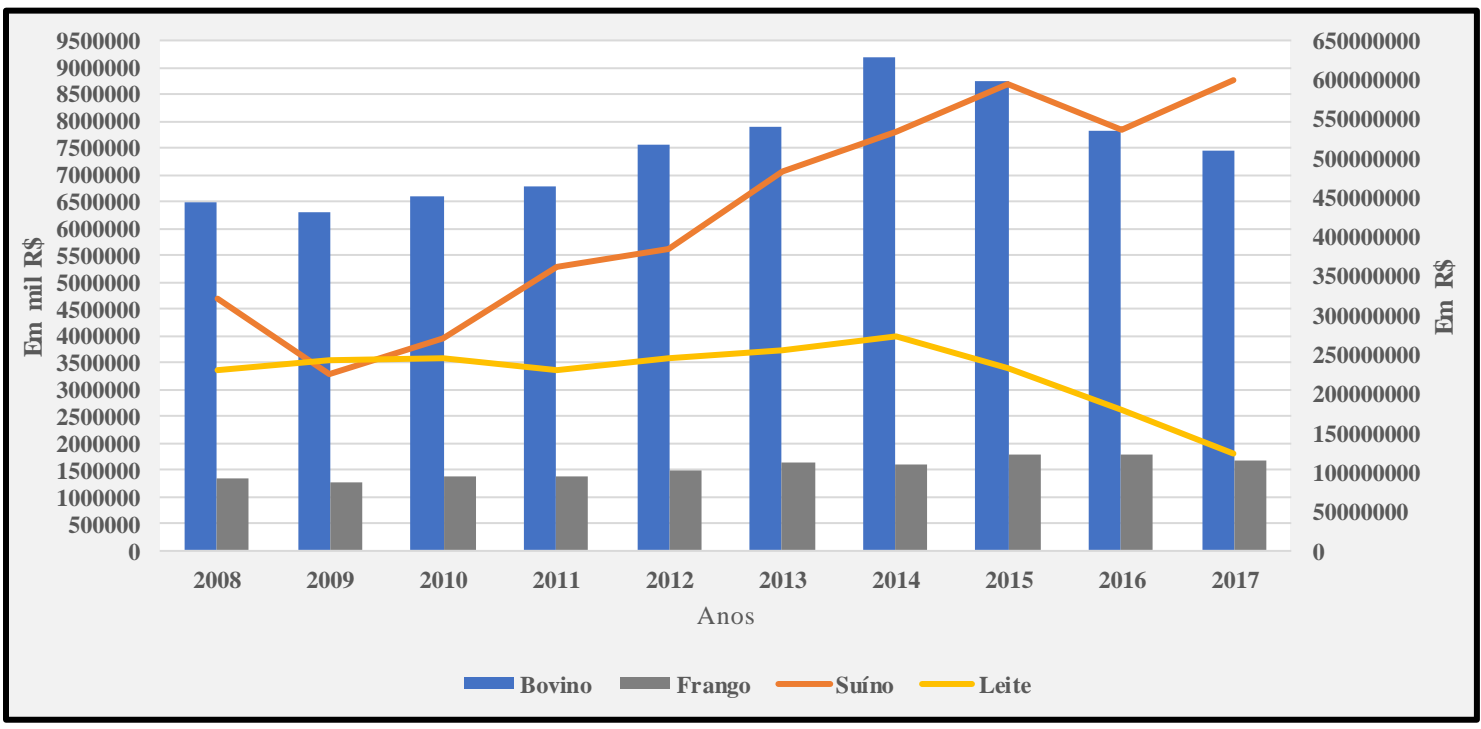

Fonte: (BRASIL, 2018b). Elaboração: autores

Em tautocronismo com o aumento do VBP nos produtos sul-mato-grossenses da pecuária, exceto o leite, entre 2003-2017 (Tabela 2), a variação acumulada do crescimento do número de animais abatidos alcançou 3,7\% (atingindo 3,4 milhões de abatimentos), e a quantidade produzida de carne bovina em carcaças foi $14,8 \%$, ficando no último ano da série em 868 mil toneladas. Na escala das mesmas dimensões, o segmento suíno representou um aumento de 95,5\% no abatimento de animais (passou de 834 mil para 1,6 milhão de cabeças), contra aumento de $110 \%$

\footnotetext{
${ }^{14}$ No Brasil, são nítidas essas diferenciações causadas por um conjunto de combinações naturais, culturais e econômicas. Cholley (1964b, p. 273) assinala ainda que, se desejamos compreender os fenômenos econômicos, sem cair em verdadeiras abstrações, com falsas individualidades, devemos situá-los nas combinações geográficas, pois esses fenômenos interagem com fatores sociais, políticos, biológicos, etc. A verdadeira Geografia Econômica não é uma simples técnica da Economia Política, em que se calculam apenas os custos e os rendimentos de certas atividades. Para ser realmente uma Geografia Econômica, deve ser, também, uma Geografia Social. E essa Geografia Econômica pode ser regional, não como um inventário de tipologias, mas sim fornecendo subsídios necessários para formulações teóricas.
} 
no amontoado na produção de carne (de 70 mil toneladas para 147 mil). Na Tabela 2, ainda, chama a atenção o período o crescimento de $50,8 \%$ de abate e $75,4 \%$ na produção de carcaças de frangos (no derradeiro ano do período, respectivamente, alcançou 169 milhões de cabeças e 451 mil toneladas). Contudo, a produção de leite apresentou um arranque dinâmico negativo de $26,4 \%$ no período de análise, diminuindo de 481 milhões para 354 milhões de litros ${ }^{15}$.

Tabela 2 - Abate de animais e quantidade produzida de carcaças

\begin{tabular}{l|l|l|l|l|l|l|l}
\hline & $\mathbf{2 0 0 3}$ & $\mathbf{2 0 0 5}$ & $\mathbf{2 0 0 8}$ & $\mathbf{2 0 1 0}$ & $\mathbf{2 0 1 2}$ & $\mathbf{2 0 1 4}$ & $\mathbf{2 0 1 7}$ \\
\hline Abate bovino (em mil) & 3.311 & 3.809 & 3.189 & 3.297 & 3.988 & 3.930 & 3.434 \\
\hline Abate suíno (em mil) & 834 & 698 & 835 & 941 & 1.188 & 1.329 & 1.631 \\
\hline Abate frango (em milhões) & 112 & 120 & 133 & 145 & 141 & 157 & 169 \\
\hline Qt. pro. bovino (em mil de t) & 756 & 847 & 740 & 794 & 943 & 958 & 868 \\
\hline Qt. pro. suíno (em mil de t) & 70 & 60 & 71 & 80 & 98 & 114 & 147 \\
\hline Qt. pro. frango (em mil t) & 257 & 281 & 304 & 343 & 362 & 394 & 451 \\
\hline Qt. pro. leite (em milhões litros) & 481 & 498 & 496 & 511 & 524 & 528 & 354 \\
\hline
\end{tabular}

Fonte: IBGE (2019c). Elaboração: autores

Esse dinamismo nos agronegócios do Mato Grosso do Sul proporcionou uma nova divisão territorial do trabalho, com o aumento de participação do estado ${ }^{16}$ e do Centro-Oeste, que, conforme Espíndola (2009), se justificam, também, por investimentos, como economia de escala e de envergadura (mega-abatedouros, novos sistemas criatórios, profissionalização do produtor), economia de custo de transação na aquisição de insumos, proximidade dos mercados consumidores em potencial de crescimento, estratégias de fusões e aquisições, agricultura de precisão, mecânica embarcada, química fina e genética.

\footnotetext{
15 Na pecuária do Mato Grosso do Sul, apesar da redução das áreas de pastagens (saiu de 14,8 milhões para 12,7 milhões de hectares, segundo IBGE (2018d)) e a intensa concentração de produtores de suínos e de aves, a produção aumentou. Em cinco anos, o número de matrizes de suínos alojadas no estado cresceu de 109,7 mil para 130,5 mil cabeças, o que representa $2,75 \%$ das matrizes alojadas no Brasil. No efetivo geral do rebanho suíno, o estado aumentou de 813,3 mil em 2003, para 1,4 milhão em 2017 (IBGE, 2019b). O rebanho de frangos, no mesmo período, pulou de 24,1 milhões de cabeças para 25,7 milhões. No que tange à ordenha de vacas, o número de cabeças baixou de 486,7 mil para 230,1 mil. E o número de animais bovinos efetivos diminuiu de 24,9 milhões de cabeças, em 2003, para 21,4 milhões, em 2017 (IBGE, 2018b). Se fizermos uma relação entre rebanho/abate/carcaças, perceberemos que: (i) no segmento bovino, houve aumento de $11,4 \%$, entre 2003 e 2017, saindo de 229 kg/carcaça para 255,2 quilos; (ii) no de suínos, uma carcaça em média pesava $84,3 \mathrm{~kg}$ em 2003, passou para $91,8 \mathrm{~kg}$ em 2017, um crescimento de 8,8\%; (iii) e o aumento mais acentuado de $16,1 \%$ na produção de frango, saindo de 2,29 kg/carcaça para 2,66 kg nos anos analisados.

${ }^{16}$ Conforme BNDES (2014), o estado do Mato Grosso do Sul recebeu, entre 2007 e 2012, 256 novas indústrias, principalmente nos setores de papel celulose, frigoríficos, mineração e sucroenergético. Entre 2005 e 2013, a região Centro-oeste recebeu grande volume financeiro, investido principalmente nos setores da indústria e de infraestrutura. Os principais destaques dos investimentos referem-se ao segundo setor. Do total investido na grande região em 2013, Mato Grosso do Sul recebeu 21\%.
} 
Além do crescimento da produção e dos índices de produtividade, os agronegócios no Mato Grosso do Sul apresentaram dinamismo recente em suas exportações. Dessa maneira, foi responsável por mais de $96,4 \%$ das vendas externas totais do estado e 5,3\% do total dos agronegócios brasileiros. Entre 2003-2018 (Gráfico 4), as receitas auferidas no mercado externo obtiveram um crescimento de mais de onze vezes. Assim, enquanto as dos agronegócios passaram de US\$447 milhões para US\$ 5,4 bilhões, as totais do sul-mato-grossenses cresceram de US\$ 497 milhões para US $\$ 5,6$ bilhões.

\section{Gráfico 4 - Exportações totais, dos agronegócios e produtos do Mato Grosso do Sul}

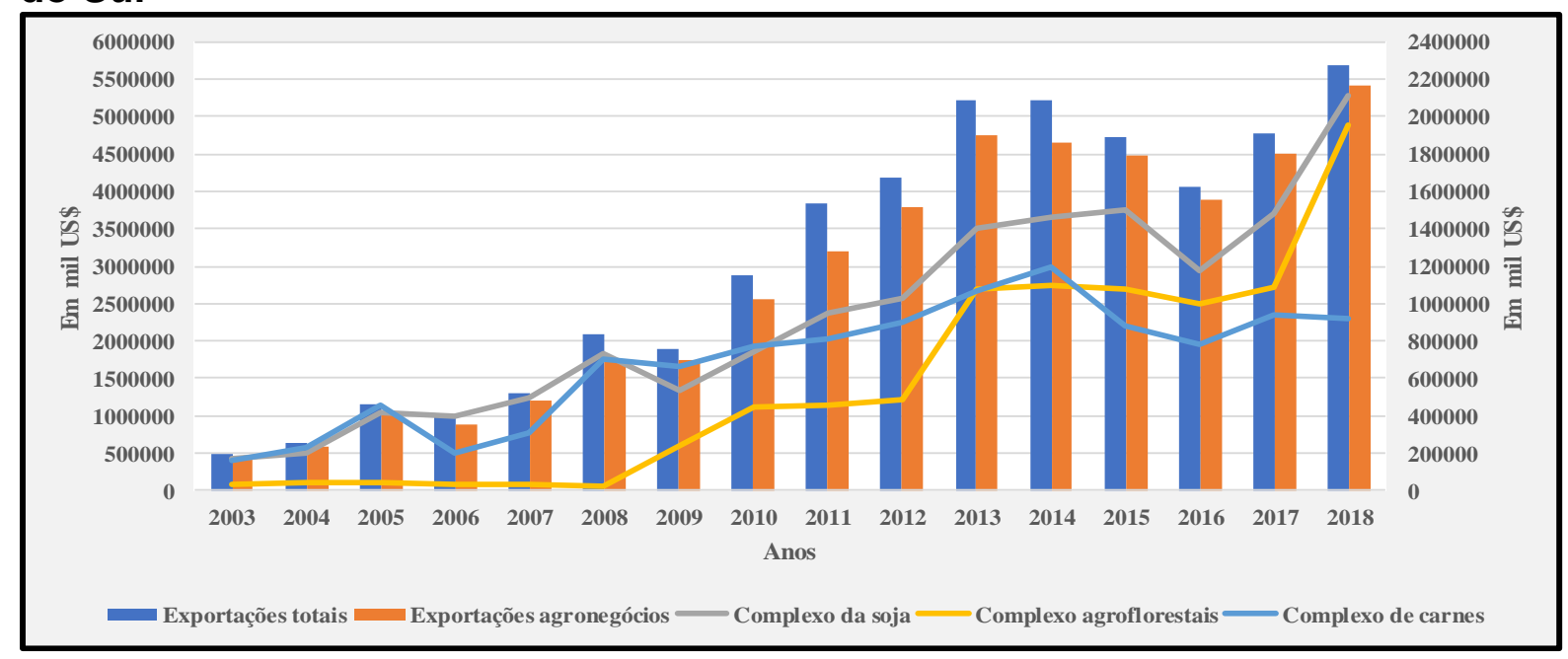

Fonte: Brasil (2019a; 2019c). Elaboração: autores

Em termos de produtos, ainda no Gráfico 4, constatamos que, as exportações de produtos de origem animal cresceram 462,5\%, passando, entre 2003-2018, de US\$ 163 milhões para US\$ 917 bilhões. As exportações do complexo da soja alcançaram uma porcentagem de $1.130 \%$, saindo de US\$ 172 milhões para US\$2,1 bilhões. Os produtos agroflorestais, no mesmo período, tiveram uma expansão no market share internacional de quase setenta vezes e atingiram US\$1,9 bilhão. A soja em grãos, a celulose e a carne bovina são as vitrines dinâmicas das vendas externas do estado do Mato Grosso do Sul no mercado internacional, sobretudo em países asiáticos.

Os desempenhos da produção, da produtividade e das exportações dos agronegócios sul-mato-grossenses manifestam-se territorialmente, pois a produção, embora concentrada em três grandes complexos, está desigualmente distribuída, promovendo, ao longo de sua evolução, concentrações produtivas territoriais. 


\section{Distribuições territoriais dos agronegócios sul-mato-grossenses}

As mesorregiões sul-mato-grossenses ${ }^{17}$, denominadas e classificadas por IBGE (2012), apresentaram, entre 2003-2017, comportamentos diferenciados, todavia com a mesma tendência de crescimento em termos de área plantada e de valor bruto da produção. Assim, entre as mesorregiões do estado, como demonstra - Gráfico 5, a mesorregião Sudoeste manteve-se em primeiro lugar no aproveitamento do solo para agricultura, uma vez que passou de 1,69 milhão de hectares para 3,5 milhões. Da mesma maneira, as mesorregiões do Centro Norte e Leste reafirmaram suas posições (segundo e terceiro lugares), com aumento na área plantada de lavouras temporários, pela ordem, de 484 mil para 1,0 milhão, 381 milhões para 653 mil hectares. A mesorregião do Pantanal também se desenvolveu, no período em tela, de 12,7 mil para 53,7 mil hectares. No acumulado, as quatro mesorregiões cresceram, na devida ordenação: 107\%; 106,6\%; 71,3\% e 322,8\%.

\section{Gráfico 5 - Área plantada de lavouras temporárias das mesorregiões do Mato Grosso do Sul}

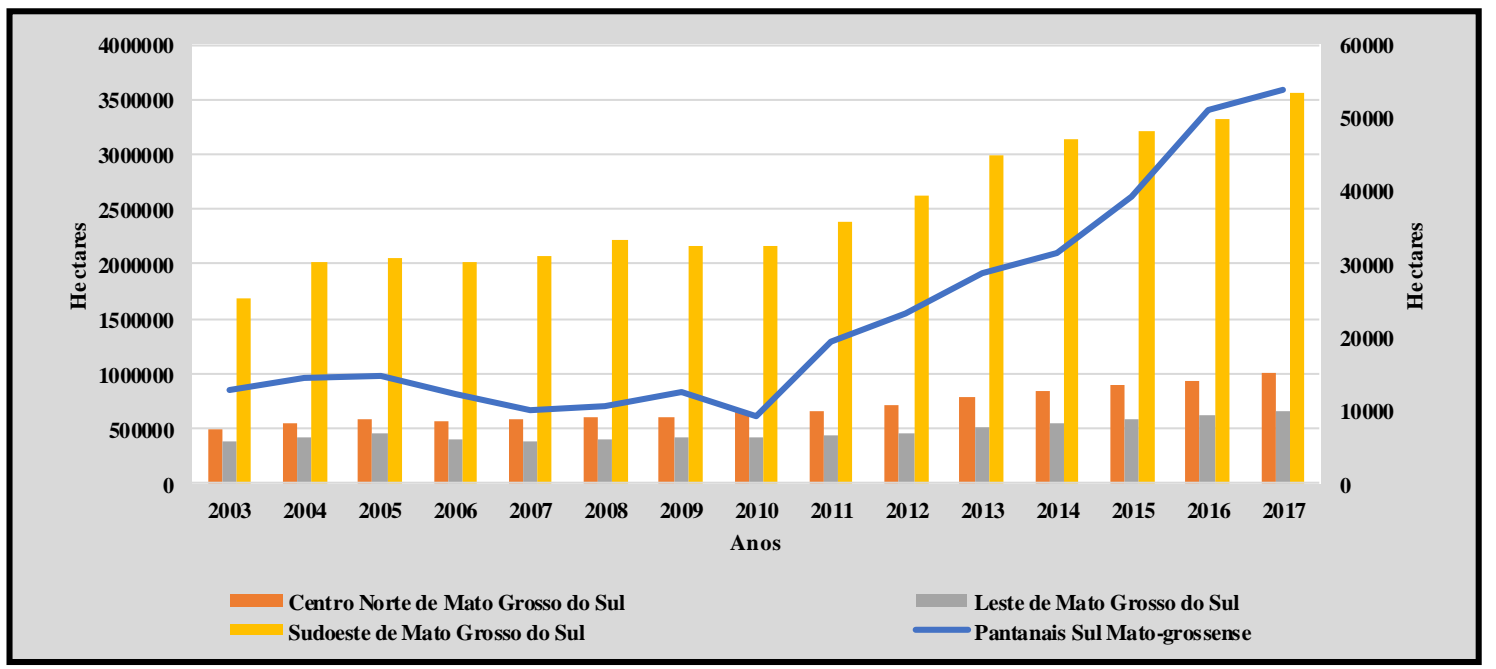

Fonte: IBGE (2019a). Elaboração: autores

\footnotetext{
17 Em 2017, o IBGE apresentou uma nova divisão regional no Brasil vinculada aos processos sociais, políticos e econômicos sucedidos em território nacional desde a última versão da Divisão Regional do Brasil, publicada na década de 1990. A revisão das unidades mesorregionais e a das microrregionais neste estudo recebe, respectivamente, os nomes de Regiões Geográficas Intermediárias e Regiões Geográficas Imediatas. "O recorte das Regiões Geográficas Imediatas e Intermediárias de 2017 incorpora as mudanças ocorridas no Brasil ao longo das últimas três décadas. O processo socioespacial recente de fragmentação/articulação do território brasileiro, em seus mais variados formatos, pode ser visualizado em vários estudos desenvolvidos no IBGE. O recurso metodológico utilizado na elaboração da presente Divisão Regional do Brasil valeu-se dos diferentes modelos territoriais oriundos de estudos pretéritos, articulando-os e interpretando a diversidade resultante" (IBGE, 2017, p. 1). Nesta seção foram considerados os novos critérios, porém foram adotados os nomes das quatro mesorregiões: Pantanais Sul-mato-grossenses (município polo Corumbá); CentroNorte do Mato Grosso do Sul (município polo Campo Grande); Leste do Mato Grosso do Sul (município polo Três Lagoas) e Sudoeste do Mato Grosso do Sul (município polo Dourados).
} 
Na variável VBP, como demonstra o Gráfico 6, todas as mesorregiões do estado do Mato Grosso do Sul tiveram variação positiva. A mesorregião Sudoeste, entre 2003-2017, obteve uma evolução nas receitas de VBP com culturas temporárias de $R \$ 2,5$ bilhões para $R \$ 10,06$ bilhões, representando um aumento de $300 \%$. O Centro Norte, que gerava $\mathrm{R} \$ 677$ milhões, aumentou o valor (295,8\%), no último ano da série, para $\mathrm{R} \$ 2,68$ bilhões. Essa tendência dinâmica também foi acompanhada pelas outras duas mesorregiões: Leste aumentou (243,8\%) de $R \$$ 666 milhões para 2,29 bilhões; e Pantanais (432,9\%) de $R \$ 27,9$ milhões para $R \$$ 148,7 milhões ${ }^{18}$.

\section{Gráfico 6 - Valor Bruto de Produção das lavouras temporárias das mesorregiões do Mato Grosso do Sul}

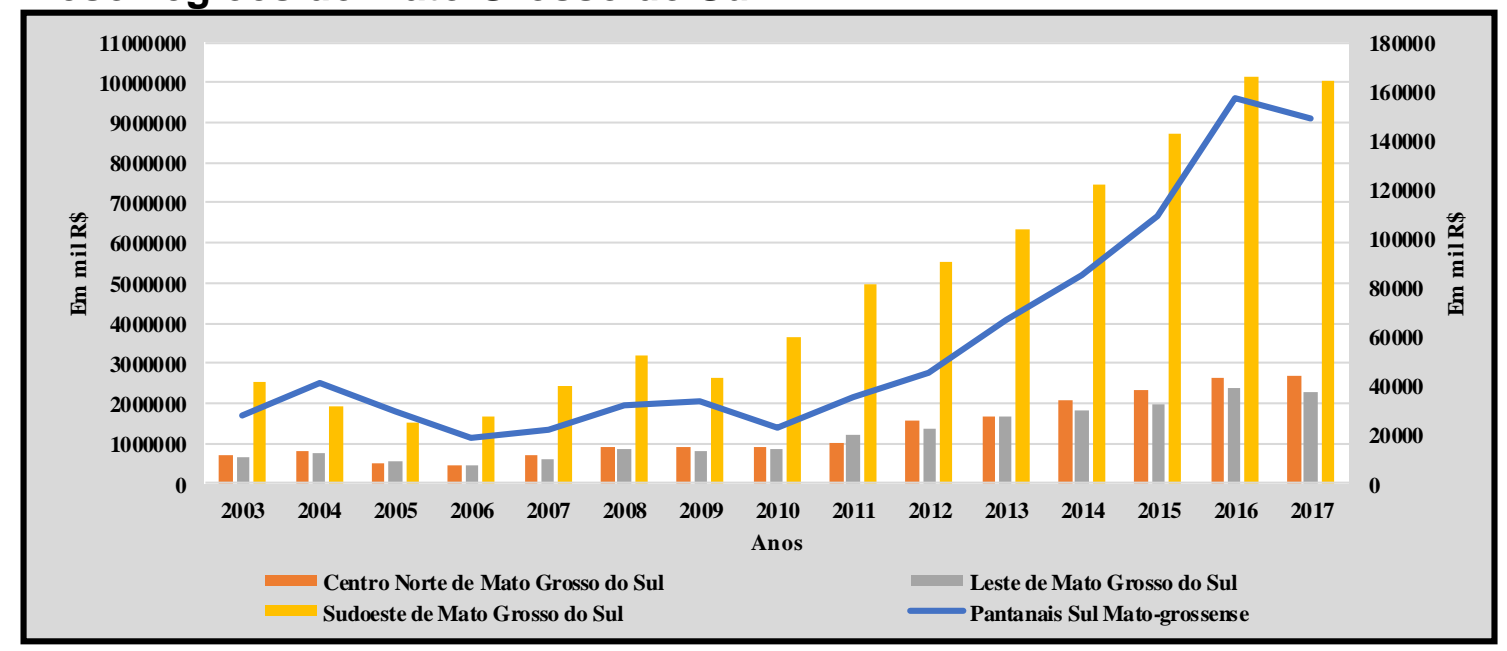

Fonte: IBGE (2019a). Elaboração: autores

Essa dinâmica mesorregional sul-mato-grossense explica-se (Tabela 3), sobretudo, em virtude do aumento dos produtos agrícolas oriundos de lavouras temporárias. A região Sudeste do estado, tendo como polo o município de Dourados, é responsável por 64,4\% (5,8 milhões de toneladas) da produção de soja estadual (5,06\% da produção nacional), 69,8\% (6,8 milhões de toneladas) da produção de milho (7\% da safra nacional), $72,9 \%$ da de cana-de-açúcar $(4,5 \%$ da produção da brasileira) e 74,7\% da produção de mandioca no estado. Em termos de variação percentual de quantidade produzida, entre 2003-2017, essa mesorregião apresentou ganhos na produção na soja (123,5\%), no milho (192\%), na cana-deaçúcar $(627,8 \%)$ e na mandioca $(27,9 \%)$, e perdas no algodão $(98,3 \%)$.

\footnotetext{
${ }^{18}$ As lavouras permanentes no estado do Mato Grosso do Sul representam apenas $0,2 \%$ da área plantada e 0,5\% do VBP. A mesorregião Leste aumentou de 2,3 mil para 6,8 mil hectares, registrando o maior aumento de VBP e atingindo, em 2017, $\mathrm{R} \$ 54,7$ milhões. E a maior queda na área plantada aconteceu na mesorregião Sudoeste, passando de 3,1 mil para 1,5 mil hectares (IBGE, 2019a).
} 
Tabela 3 - Produção dos produtos das lavouras temporárias nas mesorregiões do Mato Grosso do Sul

\begin{tabular}{|c|c|c|c|c|c|c|c|c|c|c|}
\hline \multirow{3}{*}{$\begin{array}{l}\text { Mesorregiã } \\
\text { o } \\
\text { Geográfica }\end{array}$} & \multicolumn{10}{|c|}{ Ano $x$ Produto das lavouras temporárias (toneladas) } \\
\hline & \multicolumn{5}{|l|}{2003} & \multicolumn{5}{|l|}{2017} \\
\hline & Cana & Algodã & Mandioc & Milho & Soja & Cana & Algodã & Mandioc & Milho & Soja \\
\hline Sudoeste & 476011 & 20436 & 403511 & 234815 & 262323 & 3421284 & 344 & 516126 & 685834 & 586482 \\
\hline C. Norte & 148565 & 16684 & 23065 & 341993 & 889089 & 1653793 & 13667 & 41880 & 206986 & 209455 \\
\hline Leste & 268498 & 121656 & 40563 & 378618 & 575689 & 1105900 & 117199 & 119621 & 825331 & 105088 \\
\hline Pantanais & 100074 & 284 & 18150 & 2865 & 2880 & 2 & 0 & 13125 & 68190 & 91627 \\
\hline
\end{tabular}

Fonte: IBGE (2019a). Elaboração: autores

Ainda na Tabela 3, fica evidente que a mesorregião Centro-Norte, com o polo na capital do estado de Campo Grande, apresentou variações positivas na produção de soja (135,5\%), saindo de 889 mil para 2,1 milhões de toneladas (representando $23 \%$ da safra total do estado), no milho (506,7\%), subindo de 341 mil para 2,07 milhões de toneladas ( $21 \%$ da produção do Mato Grosso do Sul). A variação do crescimento ocorreu, do mesmo modo, na produção de cana-de-açúcar, com 11,7\%, com o aumento de 1,4 milhão para 1,6 milhão toneladas (3,5\% da safra estadual). A mandioca variou de 23 mil para 41,8 mil toneladas, totalizando 81,7\% de acréscimo na quantidade produzida.

No mesmo arranque dinâmico, a mesorregião Leste (polo município de Três Lagoas) apresentou taxa afirmativa de crescimento na produção de soja de $82,6 \%$ no período, saindo de 575 mil para 1 milhão de toneladas, o que representa $11,5 \%$ da safra agrícola do produto no estado. A taxa de aumento do milho ficou em 118,3\% entre 2003 e 2017, cresceu até 825 mil toneladas e atingiu 8,4\% da produção estadual. $O$ índice mais alto foi no crescimento da quantidade produzida de cana-de-açúcar, ficando com 312\%, alcançando 11,05 milhões de toneladas. A produção de mandioca saiu de 40,5 mil para 119,6 mil toneladas, com um acréscimo de 195,3\%. Contudo, por mais que seja Leste a mesorregião mais produtora de algodão, houve involução produtiva, saindo de 121,7 mil para 117,1 mil toneladas. Por fim, na Tabela 3, ainda na dinâmica regional do Mato Grosso do Sul, a mesorregião dos Pantanais é a menos expressiva na agricultura. A soja e o milho, em 2017, alcançaram, respectivamente, 91,6 mil e 68,1 mil toneladas.

Com base no exteriorizado, pode-se afirmar que vem ocorrendo um processo de reconfiguração regional da produção dos agronegócios, caracterizado pela concentração, dispersão e exclusão. Esse processo vem redefinindo a distribuição regional dos produtos agrícolas das lavouras temporárias e provendo uma especialização produtiva territorial no estado do Mato Grosso do Sul. 
Em relação à pecuária, como se observa na Tabela 4, a concentração apresentou-se de forma acentuada no rebanho de bovinos, suínos e frangos, porém manifestou exclusão de rebanho. A mesorregião Leste do estado, na criação de bovino, em 2003, detinha 8,3 milhões; em 2017, o número caiu para 6,7 milhões de cabeças. Mesmo com a queda de 19,2\% (1,6 milhão de cabeças), a região ainda possui o maior rebanho bovino do Mato Grosso do Sul. O Sudoeste apresentou, igualmente, tendência declinante no contingente bovino; no mesmo período, a redução foi de mais de 1,7 milhão de cabeças (25,3\%), saindo de 7,1 milhões para 5,3 milhão de cabeças.

Na mesma propensão de queda, o Centro-Norte expressou uma taxa negativa de 4,4\% (236 mil cabeças), passando de 5,4 milhões para 5,1 milhões de cabeças. Senão pois, a única região que houve impulso dinâmico positivo foi a Pantanais Sulmato-grossense, a qual obteve um acréscimo de 104 mil cabeças (2,5\%), registrando 4,16 milhões, em 2003, e, em 2017, 4,27 milhões de cabeças ${ }^{19}$.

\begin{tabular}{|c|c|c|c|c|c|c|}
\hline \multirow{3}{*}{$\begin{array}{l}\text { Mesorregiões } \\
\text { geográficas }\end{array}$} & \multicolumn{6}{|c|}{ Ano x rebanho (cabeças) } \\
\hline & \multicolumn{3}{|l|}{2003} & \multicolumn{3}{|l|}{2017} \\
\hline & Bovino & Suíno & Frango & Bovino & Suíno & Frango \\
\hline Sudoeste & 7111256 & 394550 & 13084696 & 5334027 & 783723 & 12891600 \\
\hline C. Norte & 5402075 & 211384 & 8928636 & 5165971 & 413228 & 10123690 \\
\hline Leste & 8303153 & 171787 & 1438542 & 6702978 & 210639 & 2452700 \\
\hline Pantanais & 4167337 & 35638 & 695788 & 4271717 & 24987 & 265500 \\
\hline
\end{tabular}

Fonte: IBGE (2019b). Elaboração: autores

Percebe-se, além disso, na Tabela 4, que o rebanho suíno se concentrou mais ainda. Em 2003, a mesorregião do Sudoeste detinha 48,4\% (394 mil cabeças) de todo o rebanho suíno do estado. Em 2017, esse índice passou para 54,6\% (783 mil cabeças). Tanto quanto, no primeiro ano, a Centro Norte e a Leste retinham 25,9\% (211 mil cabeças), a primeira, e 20,2\% (171 mil cabeças) a segunda. Em 2017, o Market share de ambas as regiões passou de 28,8\% (413 mil cabeças) e 14,6\% (210 mil cabeças); houve, portanto, concentração e desconcentração,

\footnotetext{
${ }^{19}$ Quando tratamos dos produtos derivados da pecuária bovina, sobretudo o leite, nos últimos quinze anos, a produção diminuiu em todas as mesorregiões do Mato Grosso do Sul: Sudoeste $-12,5 \%$; Centro- Norte - 35,7\%; Leste - 32\%; Pantanais - 40,8\% (IBGE, 2019b). Mesmo que a produtividade média por vaca ordenhada tenha aumentado, a queda da produção de leite é explicada, também, pela dinâmica involutiva da quantidade de vacas ordenhadas. No período em tela, a queda regional foi a seguinte: Sudoeste - 42,5\%; Centro-Norte - 54,9\%; Leste - 60,4\%; Pantanais - 56\% (IBGE, 2019b).
} 
respectivamente. Na região dos Pantanais, ocorreu uma dispersão no número dos suínos, passando de 35 mil para quase 25 mil cabeças ${ }^{20}$.

Por derradeiro, na Tabela 4, nota-se ainda que se mantiveram a concentração e a dispersão, com um aumento na criação de frango em três mesorregiões do Mato Grosso do Sul; dentro de área, no entanto, ocorreu desconcentração interna no rebanho. Isso pois a Sudoeste, em 2003, representava 54\% (13,08 milhões de cabeças) do rebanho no estado, e passou para $50 \%$ (12,8 milhões de cabeças), em 2017. A Centro-Norte saiu de 36,9\% (8,9 milhões de cabeças) para 39,3\% (10,1 milhões de cabeças) no mesmo período. E a mesorregião Leste, que possuía 5,9\% (1,4 milhão de cabeças) ficou com, no fim da série, 9,5\% (2,3 milhões de cabeças). O Pantanal sul-mato-grossense obteve dinâmica negativa e seu rebanho de frango diminuiu, sofrendo acentuada queda na ordem de $61,8 \%$, saindo de 695 mil para 265 mil cabeças.

No tangente, da silvicultura, sobretudo da madeira para celulose, no estado do Mato Grosso do Sul (Gráfico 7), em quinze anos, a produção quase decuplicou. Em 2003, a quantidade produzida era de 1,3 milhão de metros cúbicos, em 2017 atingiu 12,8 milhões. O estado é o quarto maior produtor do Brasil, o que representa $14,6 \%$ de toda a produção nacional.

\section{Gráfico 7 - Produção de madeira para celulose no Brasil, Mato Grosso do Sul e Leste do Mato Grosso do Sul entre 2003 e 2017}



Fonte: IBGE (2019c). Elaboração: autores

20 Segundo o IBGE (2019b), nos últimos cinco anos, o número de matrizes de suínos nas três principais mesorregiões produtoras aumentou na seguinte ordem: Sudoeste $-24,4 \%$; Centro-Norte $13,9 \%$; Leste $-29,2 \%$. Na mesorregião dos Pantanais, a redução do número de matrizes suínas ficou em torno de $30 \%$. 
Por derradeiro, o ordenamento regional da silvicultura de madeira para celulose mostrou-se concentrado e centralizado na mesorregião Leste do Mato Grosso do Sul, com quase $100 \%$ da safra estadual.

\section{Considerações Finais}

Neste texto foi demonstrado que o processo de ocupação do território sulmato-grossense, por três portas de entrada, resultou na constituição de estruturas produtivas na agropecuária, sobretudo, caracterizadas pela presença do latifúndio pecuarista. Contudo, referidas estruturas, ao longo de sua trajetória evolutiva, especialmente na "marcha para o oeste" e no pós-1980, passaram por profundas transformações, que originaram agronegócios dinâmicos e com percentuais significativos no mercado agroalimentar.

Além disso, demonstrou-se que, no período compreendido entre 2003-2017, as alterações manifestaram-se na evolução do VBP animal e vegetal. Dessa feita, a elevação das rendas geradas consonanciou em equilíbrio com o aumento da área plantada de produtos das lavouras temporárias, com a ampliação da silvicultura de madeira de celulose e com a redução das áreas de pastagens. Em contrapartida, houve redução, ainda maior, na área plantada com lavouras permanentes. A diminuição da área de pastagens não provocou arrefecimento da produção de carcaças. Essa redução proporcionou aumento na produção e área plantada de soja, milho e cana-de-açúcar. Esses aumentos da produção decorreram, também, das boas condições climáticas, preços favoráveis, medidas político-institucionais e pelo aumento da produtividade.

Ademais, a despeito de a estrutura produtiva da agricultura apresentar-se diversificada, ocorreu, principalmente, pela inclusão, no período de análise, da canade-açúcar e da silvicultura. Demonstrou-se que vem ocorrendo um processo de reconfiguração regional da produção dos agronegócios, caracterizado pela concentração/desconcentração e exclusão.

A concentração da produção e a desconcentração dos rebanhos apresentamse de forma acentuada igualmente no rebanho de bovinos, suínos e frangos. $\mathrm{Na}$ silvicultura, houve concentração e centralização em uma única mesorregião.

Esses processos estão acelerando a especialização produtiva territorial. A concentração e dispersão se fazem, principalmente, no caso da soja em todas as regiões do estado em que o incremento anual de área e da produção tem sido significativo, substituindo áreas de pastagens. 


\section{REFERÊNCIAS}

BARBOSA, N. Dez anos de Política Econômica. In: SADER, E. (Org.). 10 anos de governos pós-neoliberais no Brasil: Lula e Dilma. São Paulo; Rio de Janeiro: Boitempo; Flacso, 2013. p. 63-101.

BERTHOLI, A. O lugar da pecuária na formação sócio-espacial sul-mato-grossense. 2006. 227 f. Dissertação (Mestrado) - Curso de Geografia, Universidade de Federal de Santa Catarina, Florianópolis, 2006.

Peculiaridades do desenvolvimento no Mato Grosso do Sul: formação sócio-espacial e pecuarização. 2012. 191 f. Tese (Doutorado) - Curso de Geografia, Universidade de Federal de Santa Catarina, Florianópolis, 2012.

BIELSCHOWSKY, R. Estratégia de Desenvolvimento e as Três Frentes de Expansão no Brasil: um desenho conceitual. Texto para Discussão. n. 1828, Brasília: IPEA. abr. 2013. p. 1-27. Disponível em:

$<$ http://www.ipea.gov.br/portal/images/stories/PDFs/TDs/td 1828.pdf>. Acesso em: 16 jan. 2019.

BNDES. Banco Nacional de Desenvolvimento Econômico e Social. Um olhar territorial para o desenvolvimento do Centro-Oeste. Rio de Janeiro: BNDES, 2014.

BRASIL. Ministério da Agricultura, Pecuária e Abastecimento. Estatísticas de comércio exterior do agronegócio brasileiro. 2018a. Disponível em:

< http://sistemasweb.agricultura.gov.br/pages/AGROSTAT.html>. Acesso em: 27 jan. 2019.

Valor Bruto da Produção Agropecuária. 2018b. Disponível em: < http://www.agricultura.gov.br/>. Acesso em: 25 jan. 2019.

Ministério da Economia, Industria, Comércio Exterior e serviços. Balança comercial. 2018c. Disponível em: < http://www.mdic.gov.br/balanca-comercial>. Acesso em: 27 jan. 2019.

CHOLLEY, A. Observações sobre alguns pontos de vista geográficos. Boletim Geográfico, Rio de Janeiro, n. 180, p. 267-276, 1964.

CONAB. Companhia Nacional de Abastecimento. Séries históricas de produção de grãos. Brasília: 2019. Disponível em: <http://www.conab.gov.br >. Acesso em: 10 jan. 2019.

CONTINI, E. et al. Evolução recente e tendências do agronegócio. Revista de Política Agrícola, Brasília, CONAB, ano XV, n. 1, jan.-fev.-mar. 2006, p. 5-28. Disponível em: <https://seer.sede.embrapa.br/index.php/RPA/article/view/475>. Acesso em: 10 jan. 2019.

CUNHA, R. C. C; ESPÍNDOLA, C. J. A Relevância do progresso técnico na consolidação da cadeia produtiva da soja no Sul do estado do Maranhão (Brasil). Geografia (Londrina), v. 25. n. 1. p. 87-106, jan./jun., 2016.

EMBRAPA Empresa Brasileira de Pesquisa Agropecuária. Transformações que melhoram a vida. 2019. Disponível em: < https://www.embrapa.br/busca-de-noticias//noticia/40796617/artigo-transformacoes-que-melhoram-a-vida>. Acesso em: 23 fev. 2019. ESPÍNDOLA, C. J. A dispersão territorial dos investimentos do agronegócio de carne. Anais de Geografia Econômica e Social, v. 2, Florianópolis: GCN, 2009. p. 251-281. Disponível 
em: <http://cadernosgeograficos.ufsc.br/aquisicao/revista-geografia-economica/>. Acesso em: 20 jan. 2019.

A dinâmica geoeconômica do agronegócio brasileiro de carnes e soja. In: LAMOSO, L. P. (Org.). Temas do desenvolvimento econômico brasileiro e suas articulações com o Mato Grosso do Sul. Curitiba: Íthala, 2016. p. 19-53.

CUNHA, R. C. C. A dinâmica geoeconômica recente da cadeia produtiva de soja

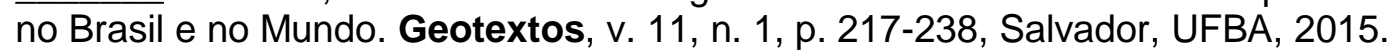

GONÇALVES, J. S. Agricultura sob a égide do capital financeiro: passo rumo ao aprofundamento do desenvolvimento dos agronegócios. Informações econômicas, São Paulo, IEA, v. 35, p. 7-36, abr. 2005. Disponível em:

$<$ http://www.iea.sp.gov.br/out/publicacoes/pdf/tec1-0405.pdf >. Acesso em: 10 fev. 2019.

IBGE. Instituto Brasileiro de Geografia e Estatística. Divisão regional do Brasil em mesorregiões e microrregiões geográficas. v. I. Rio de Janeiro, 2012. Disponível em: $<$ http://biblioteca.ibge.gov.br/visualizacao/monografias/GEBIS\%20\%20RJ/DRB/Divisao\%20regional v01.pdf>. Acesso em: 4 jan. 2019.

O recorte das regiões geográficas imediatas e intermediárias de 2017. Rio de Janeiro, 2017. Disponível em:

<https://biblioteca.ibge.gov.br/visualizacao/livros/liv100600.pdf >. Acesso em: 16 jan. 2019.

Pesquisa Agrícola Municipal. Rio de Janeiro, 2019a. Disponível em:< https://sidra.ibge.gov.br/pesquisa/pam/tabelas>. Acesso em: 16 jan. 2019.

Pesquisa Pecuária Municipal. Rio de Janeiro, 2019b. Disponível em: https://sidra.ibge.gov.br/pesquisa/ppm/quadros/brasil/2016>. Acesso em: 17 fev. 2019.

Pesquisa Trimestral do Abate de animais. Rio de Janeiro, 2019c. Disponível em: https://sidra.ibge.gov.br/pesquisa/leite/tabelas >. Acesso em: 13 fev. 2019.

Censo Agropecuário 2017. Rio de Janeiro, 2019d. Disponível em: https://sidra.ibge.gov.br/pesquisa/censo-agropecuario/censo-agropecuario-2017>. Acesso em: 12 jan. 2019.

Produção da Extração Vegetal e da Silvicultura. Rio de Janeiro, 2019e. Disponível em: <https://sidra.ibge.gov.br/tabela/291 >. Acesso em: 13 fev. 2019.

. Produto Interno Bruto dos Municípios. Rio de Janeiro, 2019f. Disponível em: <https://sidra.ibge.gov.br/tabela/5938>. Acesso em: 13 fev. 2019.

\section{LAMOSO, L. P. (org.) Temas de Desenvolvimento econômico brasileiro e suas} articulações com o Mato Grosso do Sul. Curitiba; Ithala, 2016.

MAMIGONIAN, A. A inserção do Mato Grosso ao mercado nacional e a gênese de Corumbá. Geosul, Florianópolis, v. 1, n.30, p. 39-58, 1986

OLIVEIRA, A. L. de. Grandes projetos de investimentos no Mato Grosso do Sul. 1996. 163 f. Dissertação (Mestrado) - Curso de Geografia, Sbd-fflch-usp, Universidade de São Paulo, São Paulo, 1996.

Uma Fronteira para o Pôr-doSol: um estudo geo-ecconômico sobre uma região de fronteira. 1. ed. Campo Grande: Editora da UFMS, 1998. v. 1. 147p. 
Plantando soja e colhendo um novo estado. Revista GeoPantanal v. 6, n. AgoSet, p. 79-90, 2000b.

Bordas do Pantanal (ocupação, dinamismo e meio ambiente). Geosul, Florianópolis, v. 15, n.30, p. 65-89, 2000c.

PADILHA, W.; ESPÍNDOLA, C. J. Prodecoop e Procap-agro e o crescimento das cooperativas agroindustriais da região sul. In: ENANPEGE, 11., 2015, Presidente Prudente. Anais... . Presidente Prudente: Edufgd, 2015. v. 1, p. 6187- 6198.

SEPLAN. Secretaria de Planejamento e Coordenação Geral de Mato Grosso do Sul. Macrozoneamento geoambiental do Estado de Mato Grosso do Sul. Campo Grande: Seplan-ms, 1990. 227 p.

\section{NOTAS DE AUTOR}

\section{CONTRIBUIÇÃO DE AUTORIA}

Roberto César Cunha - Concepção. Coleta de dados, Análise de dados, Elaboração do manuscrito, revisão e aprovação da versão final do trabalho.

Fernando Rodrigo Farias - Concepção. Coleta de dados, Análise de dados, Elaboração do manuscrito, revisão e aprovação da versão final do trabalho.

\section{FINANCIAMENTO}

CAPES

\section{CONSENTIMENTO DE USO DE IMAGEM}

Não se aplica.

APROVAÇÃO DE COMITÊ DE ÉTICA EM PESQUISA

Não se aplica.

\section{CONFLITO DE INTERESSES}

Não se aplica.

\section{LICENÇA DE USO}

Este artigo está licenciado sob a Licença Creative Commons CC-BY. Com essa licença você pode compartilhar, adaptar, criar para qualquer fim, desde que atribua a autoria da obra.

\section{HISTÓRICO}

Recebido em: 01-02-2019

Aprovado em: 24-02-2019 